University of Nebraska - Lincoln

DigitalCommons@University of Nebraska - Lincoln

2001

\title{
Manipulating DNA Conformation Using Intertwined Conducting Polymer Chains
}

\author{
Ramaswamy Nagarajan \\ University of Massachusetts Lowell \\ Wei Liu \\ University of Massachusetts Lowell \\ Jayant Kumar \\ University of Massachusetts Lowell \\ Sukant K. Tripathy \\ University of Massachusetts Lowell \\ Ferdinando F. Bruno \\ Natick Soldier Center, U.S. Army Soldier \& Biological Chemical Command \\ See next page for additional authors
}

Follow this and additional works at: https://digitalcommons.unl.edu/usarmyresearch

Part of the Operations Research, Systems Engineering and Industrial Engineering Commons

Nagarajan, Ramaswamy; Liu, Wei; Kumar, Jayant; Tripathy, Sukant K.; Bruno, Ferdinando F.; and Samuelson, Lynne A., "Manipulating DNA Conformation Using Intertwined Conducting Polymer Chains" (2001). US Army Research. 103.

https://digitalcommons.unl.edu/usarmyresearch/103

This Article is brought to you for free and open access by the U.S. Department of Defense at DigitalCommons@University of Nebraska - Lincoln. It has been accepted for inclusion in US Army Research by an authorized administrator of DigitalCommons@University of Nebraska - Lincoln. 


\section{Authors}

Ramaswamy Nagarajan, Wei Liu, Jayant Kumar, Sukant K. Tripathy, Ferdinando F. Bruno, and Lynne A.

Samuelson 


\title{
Manipulating DNA Conformation Using Intertwined Conducting Polymer Chains ${ }^{\dagger}$
}

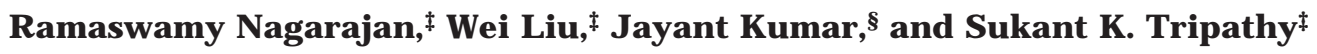

Departments of Chemistry and Physics, Center for Advanced Materials, University of Massachusetts Lowell, Lowell, Massachusetts 01854

\section{Ferdinando F. Bruno and Lynne A. Samuelson*}

Natick Soldier Center, U.S. Army Soldier \& Biological Chemical Command, Natick, Massachusetts 01760

Received December 15, 2000

\begin{abstract}
In the field of inherently conducting polymers, polyaniline (Pani) has elicited tremendous interest due to its promising electrical properties and unique redox tunability. Synthetic routes involving the use of polyelectrolytes have significantly improved the processability of polyaniline. Recently, a template guided synthesis catalyzed by an enzyme, horseradish peroxidase (HRP), has provided a means of polymerizing aniline under milder $\mathrm{pH}$ conditions $(\mathrm{pH} 4.3)$ and subsequently widened the choice of templates to more delicate bi ological macromolecules. Here we report a strategy that exploits the inherent molecular order as well as the polyelectrolyte behavior of DNA to enzymatically synthesize and biologically assemble conducting polyaniline. This "wrapping" of polyaniline on DNA has been found to induce reversible changes in the secondary structure of DNA, leading to the formation of an over-wound polymorph. The polyaniline synthesized on the DNA also exhi bited a template-induced macroasymmetry. This unique polyaniline/DNA intertwined complex has been used to "probe" and control the conformation of the DNA double helix.
\end{abstract}

\section{Introduction}

Over the past few years, the inherent properties of biological molecules such as DNA have been investigated for the devel opment of materials that could render these molecules useful beyond their typical biological function. The recognition capabilities of DNA, for example, have been used to construct silver nanowires, ${ }^{1}$ to organize colloi dal particles into macroscopic crystallike aggregates, ${ }^{2}$ and to control the shape and size of semiconductor nanoparticle assemblies. ${ }^{3}$ DNA has a unique secondary structure where the base pairs create a stack of $\pi$ electrons and this has prompted the possibility of DNA forming a "molecular conduit". ${ }^{4}$ The electronic transport properties of DNA itself have el icited significant interest. 5,6 The idea of charge transport through a DNA double helix has been a subject of great interest, and whether DNA is a conductive "molecular wire" or not is still being debated. ${ }^{7-9}$ It will be of interest in this context alone to investigate supplementation of this potential DNA conductivity through the "wrapping" of a conducting polymer chain such as polyaniline, along the DNA strands.

DNA, a natural polyelectrolyte, can also be used for the assembly of materials with specific electronic and optical properties. It has been well established that disorder is one of the limiting factors in electron/hole transport in doped conducting polymers. ${ }^{10}$ Here we report a strategy that exploits the inherent molecular order as well as the polyelectrolyte behavior of DNA to synthesize and assemble a conducting polymer, poly-

\footnotetext{
† This paper is dedicated to the memory of Professor Sukant K. Tripathy.

$¥$ Department of Chemistry.

$\S$ Department of Physics.

* To whom correspondence should be addressed.
}

aniline, where the polyaniline thus synthesized from the DNA template can be used to "probe" and control the conformation of the DNA double helix. In view of several unresolved issues related to electron transfer in DNA, the investigation of a conducting polymer that is electrostatically bound to DNA would pave the way for understanding these biological nanomaterials and would be valuable in the development of biological nanocomposites with specific electronic and optical properties.

Over the past several decades, chemical ${ }^{11-14}$ or electrochemical ${ }^{15}$ oxidation of aniline followed by protonic doping has been the most common method for the synthesis of electrically conducting polyaniline. The use of polymeric protonating ${ }^{16}$ agents for doping has improved the dopant stability in these systems. Recently, synthetic routes involving the use of polyelectrolytes have significantly improved the processability of polyaniline. ${ }^{17,18}$ The polyel ectrolyte helps to emulsify the monomer molecules prior to the polymerization, promote para coupling, and provide the requi site counterions for charge compensation in the doped polyaniline. However, the use of biological polyelectrolyte templates has been virtually nonexistent due to the harsh conditions required in these synthetic procedures.

The enzyme horseradish peroxidase (HRP) has recently been successfully employed as a catalyst for the polymerization of phenols and anilines. ${ }^{19,20} \mathrm{~A}$ template guided, enzyme catalyzed synthesis ${ }^{21}$ demonstrated the polymerization of aniline in the presence of a polyelectrolyte at near neutral $\mathrm{pH}$ conditions with significantly improved order. This enzymatic approach, involving mild reaction conditions, opened new possibilities for the use of more del icate biological polyel ectrolytes, such as DNA, as the template material. The feasibility of using the intermolecular interactions between phosphate groups and aniline monomer was first demonstrated 
with poly(vinylphosphonic acid) and DNA. ${ }^{22}$ In each case, the phosphate-based template provided the requisite local environment to facilitate the para-directed coupling of the aniline molecules.

We report here a detailed study on the formation of a unique and electrically responsive conducting DNAPani complex using this gentle enzymatic approach. The polyaniline that is formed is of interest for two reasons. First, it adopts the structural nuances and optical activity of the DNA helix, and second, it may be used to reversibly "biomanipulate" the conformation of the DNA double helix. The detailed characterization of the DNA-Pani complex using circular dichroism polarimetry, UV-vis spectroscopy, and FTIR is presented.

\section{Experimental Section}

Materials and Methods. Calf thymus DNA (lyophilized), molecular weight of the order of 50 million $\mathrm{Da}$, was obtained from Worthington Biochemical Corp., F reehold, NJ . The DNA was al ways stored bel ow $2{ }^{\circ} \mathrm{C}$ and handled in sterile conditions. DNA solutions were checked for protein contamination prior to use by measuring the UV - vis absorbance at $260 \mathrm{~nm}$ as well as $280 \mathrm{~nm}$. A DNA sample is considered free from protein impurities if $A_{260 / 280}$ is greater than or equal to $1.8 .^{23}$ Sterile glassware as well as buffers (10 mM sodium phosphate or sodium citrate) was used for the preparation of the DNA solutions. Horseradish peroxidase (HRP), type II (200 units/ $\mathrm{mg}$ ), was used for the polymerization and was purchased from Sigma Chemical Co., St. Louis, MO. Aniline monomer (purity 99.5\%) and hydrogen peroxide (30 wt \%) were purchased from Aldrich Chemicals Inc., Milwaukee, WI, and were used as received. Aniline was distilled when any coloration was observed. Hydrogen peroxide (30\%) was diluted to $0.3 \%$ (in deionized water), and this stock solution was used for polymerization.

Synthesis of Water-Insoluble DNA-Pani [DNAPani-I]. The polymerization of aniline in the presence of calf thymus DNA was carried out in sterile $10 \mathrm{mM}$ citrate or phosphate buffers. Lyophilized calf thymus DNA (200 mg) was dissolved in $400 \mathrm{~mL}$ of buffer at $\mathrm{pH} 4.3$, and the solution was stored in the refrigerator. The concentration of the DNA in solution was measured by UV absorbance at $260 \mathrm{~nm}$ after 48 $\mathrm{h}$ of dissolution and was determined to be $1.15 \mathrm{mM}$. To this DNA solution, $42.2 \mu \mathrm{L}(1.15 \mathrm{mM})$ of aniline was added. The $\mathrm{pH}$ of the solution was again checked and adjusted to $\mathrm{pH}$ 4.3. A solution of HRP (10 mg in $2 \mathrm{~mL}$ ) was then added to this and continuously stirred. The reaction was then initiated with the addition of hydrogen peroxide $\left(\mathrm{H}_{2} \mathrm{O}_{2}\right)$. To avoid the inhibition of HRP due to excess $\mathrm{H}_{2} \mathrm{O}_{2}$, a $0.3 \%$ solution of $\mathrm{H}_{2} \mathrm{O}_{2}$ was added dropwise ( $474 \mu \mathrm{L}, 1.15 \mathrm{mM})$, and the reaction mixture was stirred for 90 min after which a dark green DNA-Pani complex precipitated out of solution. The DNA-Pani complex was filtered and washed with acidified chloroform in order to remove unreacted monomer and oligomers. The precipitate was finally washed with acidified deionized water and dried under vacuum at $40{ }^{\circ} \mathrm{C}$ for $72 \mathrm{~h}$. The gravimetric yield was approximately $75 \%$.

Synthesis of Water-Soluble DNA-Pani [DNAPani-S] Complex. The procedure used for preparing a watersoluble DNA-Pani-S complex is similar to that described previously except that a smaller amount of hydrogen peroxide is used. In this case the extent of polymerization is lower, leaving a higher amount of free DNA phosphate groups to improve solubility. After optimization, it was found that addition of $95 \mu \mathrm{L}$ of the $0.3 \% \mathrm{H}_{2} \mathrm{O}_{2}$ solution was sufficient to both polymerize the aniline and form a water-soluble DNA complex. The water-soluble complex was then transferred to individual regenerated natural cellulose membrane bags (molecular weight cutoff $1000 \mathrm{Da}$ ) and was dialyzed against 5000 $\mathrm{mL}$ of acidified deionized water maintained at $\mathrm{pH}$ 4.3. Dialysis was carried out for $72 \mathrm{~h}$ with fresh acidified dei onized water being added every $12 \mathrm{~h}$ to expedite the removal of oligomers and unreacted monomer. This solution was used for doping-

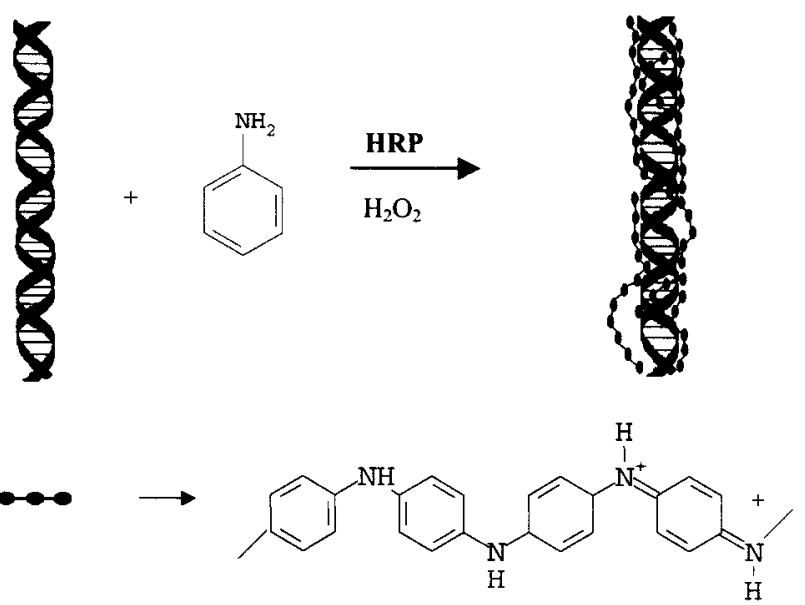

Figure 1. Schematic representing the formation of polyaniline on DNA.

dedoping and conformational switching studies. The dry solid DNA-Pani-S complex was obtained by the evaporation of solvent and drying at $40^{\circ} \mathrm{C}$ under vacuum for $72 \mathrm{~h}$.

For time-resolved experiments, $10 \mathrm{~mL}$ of the DNA solution was used for the synthesis. Aniline of equi molar concentration was added to the DNA solution and mixed gently. A $15.5 \mu \mathrm{L}$ aliquot of a freshly prepared stock solution of horseradish peroxidase (1 mg in $100 \mu \mathrm{L}$ ) was added to the mixture. Hydrogen peroxide solution $(0.098 \mathrm{M})$ was added dropwise to the reaction mixture, over a period of $1 \mathrm{~h}$ with gentle mixing. The amount of hydrogen peroxide added was limited to one fifth of the stoichiometric equivalent of aniline present in the reaction mixture to prevent precipitation of the DNA-Pani complex.

Characterization. UV-vis spectra of DNA and DNApolyaniline solutions were obtained with a HP diode array detector photometer (type HP8452A) and a Perkin-Elmer Lambda 9 spectrophotometer. Circular dichroi sm (CD) spectra were obtained using a J asco CD spectrometer J -720. The CD measurements were done in either 1 or $10 \mathrm{~mm}$ quartz cuvettes, and the data were normalized to represent measurements made on $1 \mathrm{~mm}$ cuvettes. Fourier transform infrared spectroscopy (FTIR) was carried out using a Perkin-EImer 1720X series FT-IR spectrophotometer. The samples were either cast on Zinc selenide disks and dried or were in the form of $\mathrm{KBr}$ pellets.

\section{Results and Discussion}

Optimization of Reaction Conditions and Stoichiometry of the DNA-Pani Complex. When aniline monomer is added to a DNA solution at $\mathrm{pH} 4.0$, the aniline molecules become protonated, and the electrostatic interaction between the protonated aniline and the phosphate groups in the DNA results in close association of the protonated aniline with the DNA. This high proton concentration around the phosphate groups provides a unique local environment that permits polymerization of aniline at a higher $\mathrm{pH}$ than the conventional chemical synthetic methods and facilitates a predominantly para-directed coupling that deters parasitic branching during the polymerization. ${ }^{24} \mathrm{~A}$ schematic illustrating the formation of polyaniline in the presence of DNA is illustrated in Figure 1 . However, if the polymerization is allowed to proceed too far and a critical chain length is attained, the DNA-Pani complex precipitates out of solution. Therefore, in an attempt to optimize the extent of polymerization required for maintaining the complex in a soluble form, as well as for determining the composition of polyaniline and DNA in the complex prior to precipitation, a matrix of reaction 


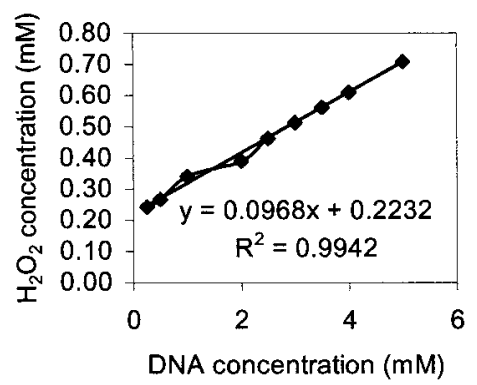

Figure 2. DNA concentration $\mathrm{vs}_{2} \mathrm{O}_{2}$ concentration required for precipitation.

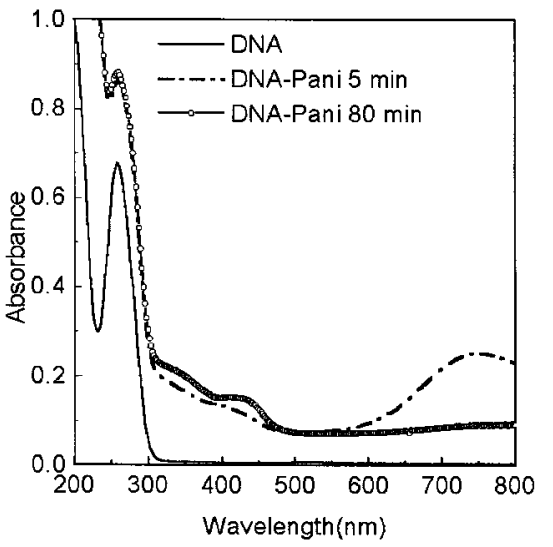

Figure 3. UV-vis spectra of DNA only, DNA-polyaniline (5 $\mathrm{min})$, and DNA-polyaniline (80 $\mathrm{min}$ ).

systems was set up. In these experiments, the molar ratio of DNA:aniline in the reaction medium was varied from 0.25:1 to 5:1, while the amount of enzyme was kept constant in all cases. The extent of polymerization was controlled by incremental addition of $\mathrm{H}_{2} \mathrm{O}_{2}$ until the onset of precipitation. In all cases the reaction mixture contained $10 \mathrm{~mL}$ of buffer, $0.15 \mathrm{mg}$ of HRP, and $1 \mathrm{mM}$ aniline. $\mathrm{A} 0.3 \% \mathrm{H}_{2} \mathrm{O}_{2}$ solution was used to carry out the polymerization, and $25 \mu \mathrm{L}$ of this solution was added to the reaction mixtures every $1.5 \mathrm{~min}$ until precipitation of the complex was observed. Figure 2 is a plot of the amount of $\mathrm{H}_{2} \mathrm{O}_{2}$ required to precipitate the DNAPani complex with $1 \mathrm{mM}$ aniline in the reaction medium, while varying only the concentration of DNA. Assuming that the amount of $\mathrm{H}_{2} \mathrm{O}_{2}$ corresponds to the extent of polymerization, the slope of the curve (Figure 2) gives a molar ratio of approximately 10:1 for DNA to aniline repeat unit. These results show that the amount of $\mathrm{H}_{2} \mathrm{O}_{2}$ required for precipitation increases linearly with the concentration of DNA in solution. Considering the mechanism of HRP-catalyzed polymerization, it is reasonable to expect a linear relationship between the amount of $\mathrm{H}_{2} \mathrm{O}_{2}$ added and the extent of polymerization. 25

UV-vis Spectroscopy and Circular Dichroism Polarimetry during Pani Formation. The polymerization reaction was monitored over the first $80 \mathrm{~min}$ using UV-vis spectroscopy and circular dichroism polarimetry. The UV-vis spectra of the DNA-polyaniline complex recorded at 5 and $80 \mathrm{~min}$ after initiation of the polymerization are shown in Figure 3. The UV-vis spectrum obtained at $5 \mathrm{~min}$ after initiation of polymerization shows the signature polaron absorption bands of polyaniline at 420 and $750 \mathrm{~nm}$. The bipolaron band at $750 \mathrm{~nm}$ is attributed to the formation of pernigraniline in the initial stages of the reaction. This

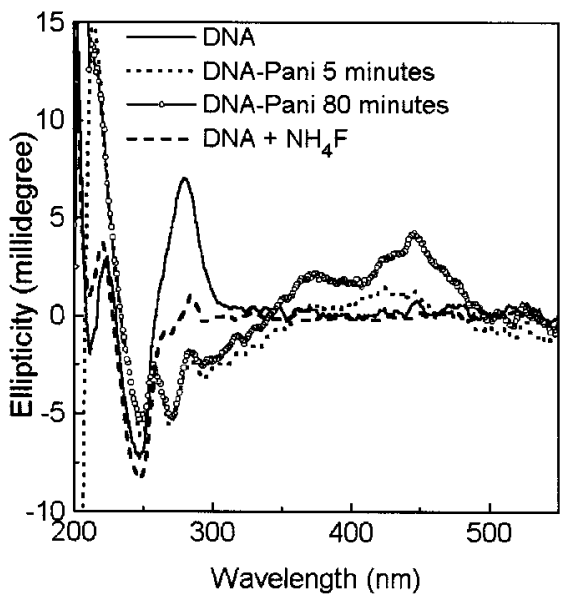

Figure 4. $C D$ spectra of $D N A$, DNA $+\mathrm{NH}_{4} \mathrm{~F}$, DNA-polyaniline (5 min), and DNA-polyaniline (80 min).

$750 \mathrm{~nm}$ band diminishes after $80 \mathrm{~min}$, while the 420 and $310-320 \mathrm{~nm}$ bands increase in intensity, indicating the formation of the conducting emeraldine salt form of polyaniline. Furthermore, a broad long wavelength absorption extending beyond $1200 \mathrm{~nm}$ is al so observed (results not shown).

The reaction was also followed using circular dichroism polarimetry. The chromophores in DNA are essentially the bases that have a plane of symmetry and thus are not intrinsically optically active. However, the deoxyribose sugar is asymmetric, and since the bases are attached to the $1^{\prime}$ carbon of these sugars, the sugar induces a circular dichroism in the absorption bands of the bases. The intensity of the CD is low because it is a secondary effect of the asymmetric sugar, inducing a CD in the chromophoric but symmetric base. The change in conformation of DNA induced by the formation of polyaniline was followed using circular dichroism spectroscopy. DNA is known to exhibit polymorphism, and the structural transition between the " $\mathrm{A}$ ", " $\mathrm{B}$ ", and " $\mathrm{C}$ " polymorphs is sensitive to the nature of solvent and salt concentration. ${ }^{26}$ Prior to the formation of polyaniline, DNA naturally exists as the " $\mathrm{B}$ " polymorph and has a characteristic $C D$ curve as shown in Figure 4. The conformation of DNA is found to change dramatically during polyaniline formation as shown by the $C D$ curves recorded at 5 and $80 \mathrm{~min}$ after initiation of polymerization. The positive peak at $220 \mathrm{~nm}$ increases in intensity, while the negative peak at $245 \mathrm{~nm}$ reduces in intensity. The positive shoulder at $270 \mathrm{~nm}$ changes to a new negative peak with fine structure. These changes are indicative of the polymorphic transition in DNA from a loosely wound "B" form (containing 10.4 base pairs per turn) to the over-wound form (containing less than 10 base pairs per turn). ${ }^{27}$

The formation of polyaniline on the DNA template is concomitant with the shielding of charges on the phosphate groups of the DNA. This shielding of charge on the phosphate groups by the polyaniline reduces the electrostatic repulsion between successive phosphate groups, leading to the formation of the over-wound polymorph. ${ }^{28}$ Changes in the conformation of DNA can also be initiated by adding large amounts of salt such as ammonium fluoride to the DNA solution (Figure 4). It has been reported that the change in the $C D$ spectrum corresponds to a change in the B-form from 10.4 base pairs per turn to 10.2 base pairs per turn. ${ }^{29}$ However, 


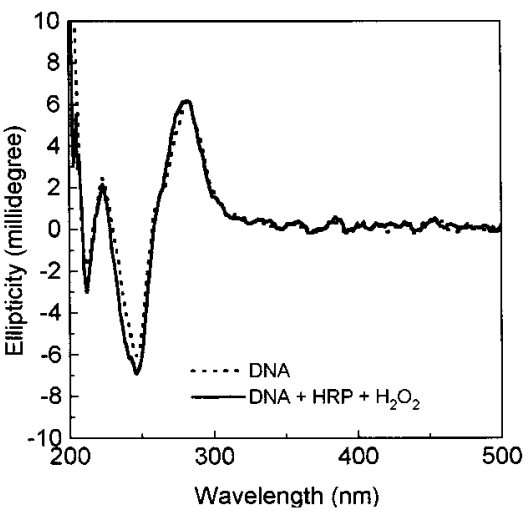

Figure 5. CD spectra of DNA and DNA with $\mathrm{HRP}$ and $\mathrm{H}_{2} \mathrm{O}_{2}$.

in this case the negative peak at $245 \mathrm{~nm}$ does not change in intensity, as it did when polyaniline is present. Additional changes in the $245 \mathrm{~nm}$ band of the DNApolyaniline complex indicate a transition similar to what is observed for a "B" to "C" polymorph transition 38 and is perhaps evidence of a new type of DNA polymorph. This significant conformational change in DNA induced by the polymerization of aniline supports the formation of a charged, emeraldine salt form of polyaniline that is complexed to the DNA template. The fact that this conformational transition occurs at such a low concentration (millimolar concentration) in comparison to the high salt concentrations (5 M) also indicates that the complexed polyaniline formed is intertwined and in intimate contact with the DNA strands.

The CD spectrum in the visible region also provides interesting information on the secondary structure of the polyaniline that is formed on the DNA template. Eighty minutes after the initiation of polymerization, the CD spectrum does not change significantly from that observed after the first 5 min in the region between 190 and $300 \mathrm{~nm}$. However, two broad, positive peaks in the visible region are observed at 365 and $445 \mathrm{~nm}$ after 80 min. This may be explained as the polyaniline threading along the helical DNA template and thus adopting a preferred handedness. Chirality and optical activity have been previously reported in colloidal complexes of polyaniline and (1R)-(-)-10-camphorsulfonic acid. ${ }^{30-32}$ In these cases, the observed macroasymmetry has been explained in terms of the polyaniline chain adopting a preferred one-sense helical screw maintained by the dopant anions via electrostatic and hydrogen-bonding interactions. ${ }^{33}$ In this case, the electrostatic interactions between the DNA double helix and the templated polyaniline are postulated to induce a macroasymmetry in the polyaniline.

To confirm that the catalytic conditions of the HRP synthesis do not affect the secondary structure of DNA, HRP and hydrogen peroxide (same concentrations as those used in the polyaniline synthesis) were added to a DNA control solution, and the CD spectrum was recorded after $80 \mathrm{~min}$ (Figure 5). The results of the CD spectra of this DNA control solution clearly show that no change occurs with the DNA under these conditions. In addition, another control of aniline and DNA (no $\mathrm{H}_{2} \mathrm{O}_{2}$ or HRP) showed no change (results not shown). Therefore, the DNA conformational changes that were observed with the aniline polymerization are attributed solely to the formation and interaction of the polyaniline with the DNA.

Doping-Dedoping Reversibility of DNA-Pani. The reversible redox behavior of the polyaniline in the

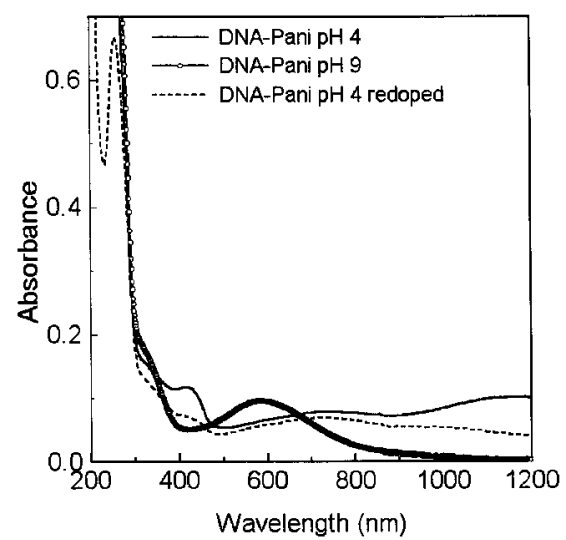

Figure 6. UV-vis spectra of DNA-polyaniline during dedoping and redoping.

DNA-Pani-S complex was studied by dedoping and doping using base and acid, respectively, and the results are presented in Figure 6 . The UV-vis spectra of the DNA-Pani-S obtained at $\mathrm{pH} 4$ show some similarity to the spectra reported earlier for the SPS/Pani complex. ${ }^{21}$ The polaron band at $420 \mathrm{~nm}$ as well as the $\pi-\pi^{*}$ transition of the benzenoid rings at $320 \mathrm{~nm}$ confirms the presence of Pani in the doped state. This shift of the polaron band to higher wavelengths has been reported earlier for electrochemically polymerized polyaniline and is attributed to the differences in the oxidation states (polaron or bipolaron) of the polymer. ${ }^{34}$ The DNA-Pani complex at pH 4 also shows a polaron band in the $750 \mathrm{~nm}$ region and longer wavelength absorption around $1150 \mathrm{~nm}$. The longer wavelength absorption in the chemically synthesized polyaniline has been interpreted in terms of the presence of the polymer chain with extended conjugation. ${ }^{35}$

When the $\mathrm{pH}$ of the solution is increased from 4 to 10 using $\mathrm{NaOH}$ solution, a decrease and subsequent disappearance of the polaron bands at 420,750, and $1000 \mathrm{~nm}$ is observed. Simultaneously, the emergence of absorption in the $580 \mathrm{~nm}$ region is observed and attributed to the exciton transition of the quinoid rings. The $320 \mathrm{~nm}$ band assigned to the $\pi-\pi^{*}$ transition of the benzenoid rings in polyaniline also increases with the increase in $\mathrm{pH}$. At $\mathrm{pH} \mathrm{10,} \mathrm{the} \mathrm{polyaniline} \mathrm{is}$ completely dedoped to form Pani base, and the corresponding absorption spectrum is comparable to a chemically synthesized polyelectrolyte-Pani complex reported earlier. ${ }^{36}$ These doping/dedoping processes are consistent with that previously observed for polyaniline and are fairly reversible as shown by the partial restoration of the original doped polyaniline spectrum. A higher level of restoration of the polaron bands is observed if the absorption spectra are recorded after several hours. In the case of the SPS-Pani-I complex, however, substantial restoration of polaron bands has been reported. ${ }^{37}$ This difference in behavior may be explained by the $\mathrm{pK}_{a}$ of the phosphonic acid repeat unit of the DNA. The $\mathrm{pK}_{a}$ of the benzenesulfonic group in SPS is much lower than that of the phosphate group in DNA. ${ }^{21}$ Therefore, at $\mathrm{pH} 4$, the DNA is less dissociated when compared with the SPS, therefore affecting the degree and reversibility of the doping/dedoping process. It is important to note however that observance of this doping/dedoping process further supports both the presence and electroactivity of polyaniline with the DNA template. 


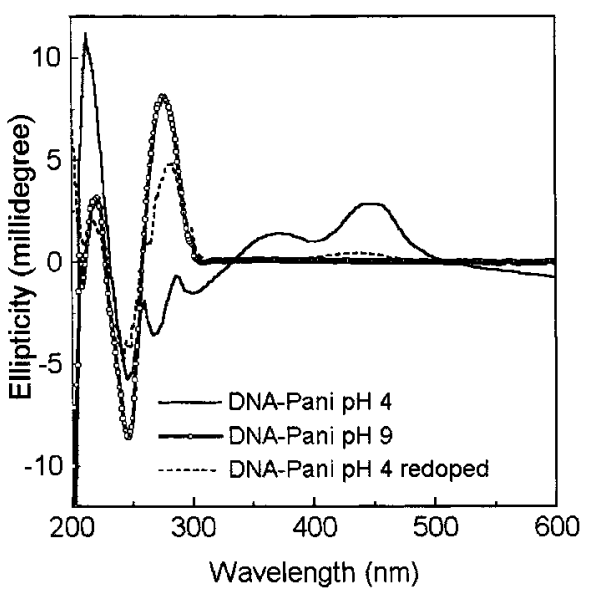

Figure 7. CD spectra of DNA-polyaniline during dedoping and redoping.

Conformational Switching. The next question to address was whether the conformation of the DNA could be reversibly controlled through the electroactivity of the polyaniline. Therefore, the change in the conformation of DNA in the DNA-Pani complex during the dedoping and redoping process was followed using circular dichroism polarimetry. Figure 7 shows the $C D$ curve of the DNA-Pani under various $\mathrm{pH}$ conditions and confirms that the conformation of the DNA can be switched with almost complete reversibility by doping and dedoping the polyaniline. When the $\mathrm{pH}$ of the DNA-Pani solution is increased, the CD spectrum changes significantly, and at $\mathrm{pH} 9$ it is very similar to that observed for DNA without the polyaniline. This behavior is attributed to a dedoping of the polyaniline that in turn minimizes the el ectrostatic attraction and proximity of the polyaniline with the charged phosphate groups on the DNA. This then allows the inherent charge repulsion of the DNA phosphate groups to dominate and thus promote an uncoiling of the DNA back to its native state. The changes in the $C D$ bands at 275 and $245 \mathrm{~nm}$ are similar to that observed for a polymorphic transition between the " $\mathrm{C}$ " and " $\mathrm{B}$ " form of DNA. ${ }^{37}$ The recovery of the CD bands in the $275 \mathrm{~nm}$ region may also be explained in terms of the DNA molecule undergoing a transition where the number of base pairs per turn is decreased from 10.4 to 10.2. The polyaniline $C D$ peaks at 365 and $445 \mathrm{~nm}$ also change significantly and are completely lost at pH 9. This CD loss may similarly be explained as a "loosening" of the dedoped polyanil ine from the DNA strands, thus losing the macroasymmetry that was observed for the more tightly bound doped polyaniline. The UV-vis absorption of this sol ution al so decreases at these wavelengths and confirms that dedoping of the polyaniline has occurred.

Subsequently, the CD spectra in Figure 7 show that when the DNA-Pani solution is redoped, the charge on the polyaniline reverts the DNA back to the over-wound form. This is confirmed by the collapse of the $275 \mathrm{~nm}$ band and also by the reduction of the intensity of the $245 \mathrm{~nm}$ band. These changes are indicative of a polymorphic transition between the " $\mathrm{C}$ " form and " $\mathrm{B}$ " form. To obtain unambiguous proof that the charged state of the polyaniline is the driver of the DNA polymorphic transition, the $C D$ of DNA only under varying $\mathrm{pH}$ conditions was studied. Figure 8 gives the CD curve of DNA as the $\mathrm{pH}$ ranges from 4 to 10 and back to $\mathrm{pH} 4$. As shown, there is a negligible change in the CD spectra of the pure DNA with $\mathrm{pH}$. This confirms that the

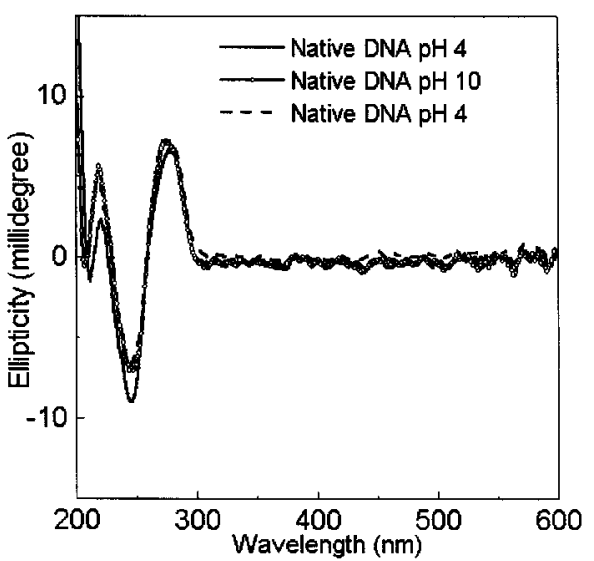

Figure 8. $\mathrm{CD}$ spectra of native DNA (only) solution at $\mathrm{pH} 4$ and $\mathrm{pH} 10$.

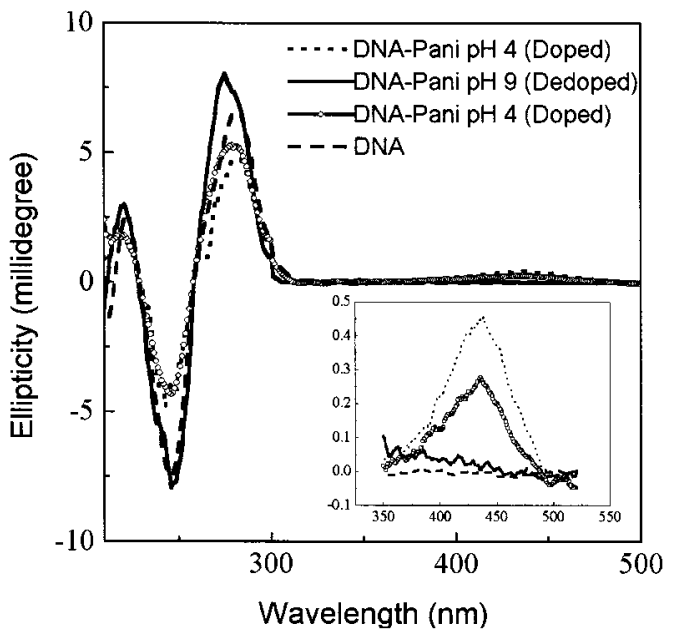

Figure 9. CD spectra of DNA-polyaniline during the second doping and dedoping cycle.

charged state of the polyaniline directly influences the conformation of the DNA in the DNA-Pani complex.

Conformational Reversibility. It was found however that the recovery of the CD and UV spectra after the first dedoping/redoping cycle is not complete, although it does improve with time. This incomplete recovery of the CD peaks is explained by partial precipitation and loss of the more weakly complexed polyaniline upon dedoping. To determine the reversibility of this process after the first cycle, with the more tightly bound polyaniline remaining complexed to the DNA, the dedoping and redoping of polyaniline was carried out for a second time using the same DNA - Pani solution. The CD curves obtained after this second cycle show improved conformational reversibility and are shown in Figure 9. As mentioned previously, the changes in CD bands at 285, 275, and $245 \mathrm{~nm}$ are indicative of a transition between the " $B$ " and " $C$ " polymorphs of DNA. The average conformational recovery calculated on the basis of these CD bands for the second dedopingredoping cycle was found to be over $75 \%$. The inset in Figure 9 indicates the change in the conformation of the polyaniline bound to the DNA where the conformational reversibility of the polyaniline is found to be over $60 \%$ (calculated on the basis of the $435 \mathrm{~nm}$ peak). This significantly higher conformational recovery in the second cycle is presumably due to a higher contribution of more strongly complexed polyaniline to the doping and redoping process. In other words, the polyaniline 


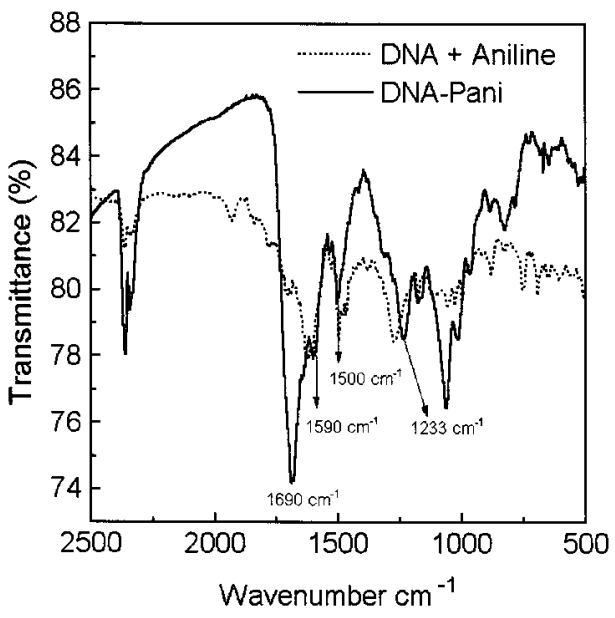

Figure 10. FTIR comparison spectra of a physical mixture of DNA with aniline vs DNA-Pani-I.

strands that are weakly complexed with DNA are lost during the first doping-dedoping cycle, and the polyaniline that remains wound after the first cycle is substantially well complexed with the DNA.

FTIR Characterization of the DNA-Pani Complex. The FTIR spectra of DNA-Pani and a physical mixture of DNA and aniline are compared and shown in Figure 10. Ring stretch of the polyaniline quinoid form has been observed as a broad band at $1590 \mathrm{~cm}^{-1}$ (at a slightly higher wavenumber than the expected value of $1580 \mathrm{~cm}^{-1}$ ) while the ring stretch of the benzenoid form appears as a significantly broad band centered around $1500 \mathrm{~cm}^{-1}$. The intense peak at 1690 $\mathrm{cm}^{-1}$ has been attributed to the $\mathrm{C}=\mathrm{N}$ stretch of the quinoid form. The characteristic IR absorption band at $825 \mathrm{~cm}^{-1}$ has been assigned to the sugar-phosphodiester $(\mathrm{O}-\mathrm{P}-\mathrm{O})$ vibrational frequency in DNA. ${ }^{39}$ The electrostatic interaction between the polyaniline and DNA matrix results in the intense broadening of this peak in the DNA-Pani complex. The antisymmetric stretching vibration of the $\mathrm{PO}_{2}^{-}$groups at $1275 \mathrm{~cm}^{-1}$ in the free DNA has shifted to $1233 \mathrm{~cm}^{-1}$ in the DNAPani, indicating interaction of the polyaniline with the phosphate groups of the DNA.

\section{Conclusion}

An enzyme-catalyzed synthesis and complexation of polyaniline on a biological polyelectrolyte matrix (DNA) is reported. Circular dichroism polarimetry and UVvis spectroscopic studies show that electroactive polyaniline is formed and intertwined with the DNA. The secondary structure of the DNA may be reversibly controlled from the native form to an overwound polymorph by simply changing the redox state of the polyaniline. In addition, the polyaniline formed mimics the helicity of the DNA and adopts a preferred handedness of its own. This approach is generic and can be extended to numerous other biological polyelectrolytes and monomers to yield biomacromolecular complexes with interesting optical, electrical, and structural properties. The binding of an electroactive polymer to a biological matrix and the ability to control the conformation of the matrix opens new possibilities for fundamental studies of biological molecules as well as the development of unique biosensors, nanowires, and diagnostic tools.
Acknowledgment. We thank Prof. David Kaplan, Mr. Lars Waldmann, and the Tufts Biotechnology Center for assistance with the circular dichroism measurements.

\section{References and Notes}

(1) Braun, E.; Eichen, Y.; Sivan, U.; Ben-Yoseph, G. Nature 1998 391, 775-778.

(2) Alivisatos, A. P.; Peng, X. G.; Wilson, T. E.; Loweth, C. J .; Bruchez, M. P.; Schultz, P. G. Nature 1996, 382, 609-611.

(3) Colvin, V. L.; Goldstein, A. N.; Alivisatos, A. P.J . Am. Chem. Soc. 1992, 114, 5221-5230.

(4) Wilson, E. K.Chem. Eng. News J uly 1998, 51-54.

(5) Kelley, S. O.; Barton, J. K. Science 1999, 283, 375-381.

(6) Kelley, S. O.; Barton, J. K. Chem. Biol. 1998, 8, 413-425.

(7) Arkin, M. R.; Stemp, D. A.; Holmlin, R. E.; Barton, J. K.; Hormann, A.; Olson, J . C.; Barbara, P. F. Science 1996, 273, 475-480.

(8) Brun, A. M.; Harriman, A. J. Am. Chem. Soc. 1992, 114, $3656-3660$

(9) Meade, T. J .; Kayyem, J . F. Angew. Chem., Int. Ed. Engl. 1995, 34, 352-354.

(10) Menon, R.; Yoon, C. O.; Moses, D.; Heeger, A. J . In Handbook of Conducting Polymers, 2nd ed.; Skotheim, T. A., Elsenbaumer, R. L., Reynolds, J . R., Eds.; Marcel Dekker: New York, 1998; pp 27-28.

(11) Chen, S. A.; Hwang, G. W. J . Am. Chem. Soc. 1995, 117, 10055-10062.

(12) Chan, H. S. O.; Ng, S. C.; Ho, P. K. H. J . Am. Chem. Soc. 1995, 117, 8517-8523.

(13) Yue. J .; Epstein, A. J . J . Am. Chem. Soc. 1990, 112, 28002807.

(14) Liao, Y. H.; Levon, K.; Osterholm, J . E. Macromol. Rapid Commun. 1995, 16, 393-397.

(15) Diaz, A. F.; Logan, J . A. J . Electroanal. Chem. Interfacial Electrochem. 1980, 111, 111-114.

(16) Bartlett, P. N.; Wang, J . H. J . Chem. Soc., Faraday Trans. 1996, 92, 4137-4143.

(17) Liu, J -M.; Sun, L.; Hwang, J .; Yang, H. S. C. Mater. Res. Soc. Symp. Proc. 1992, 247, 601-602.

(18) Sun, L.; Liu, H.; Clark, R.; Yang, S. C. Synth. Met. 1997, 84 , 67-68.

(19) Dordick, J . S. Enzyme Microb. Technol. 1989, 11, 194-211.

(20) Akkara, J. A.; Senecal, K. J .; Kaplan, D. L. J . Polym. Sci., Polym. Chem. 1991, 29, 1561-1574.

(21) Liu, W.; Kumar, J .; Tripathy, S. K.; Senecal, K. J .; Samuelson, L. J . Am. Chem. Soc. 1999, 121, 71-78.

(22) Nagarajan, R.; Tripathy, S.; Kumar, J .; Bruno, F. F.; Samuelson, L. Macromolecules 2000, 33, 9542-9547.

(23) Sambrook, J.; Fritsch, E. F.; Maniatis, T. In Molecular Cloning, 2nd ed.; Cold Spring Harbor Laboratory Press: New York, 1989; Book 3, p 7.6.

(24) Liu W.; Cholli, A. L.; Nagarajan, R.; Kumar, J .; Tripathy, S. K.; Bruno, F. F.; Samuelson, L. J . Am. Chem. Soc. 1999, 121 $11345-11355$

(25) Dunford, H. B. In Peroxidases in Chemistry and Biology; Everse, J ., Everse, K. E., Grisham, M. B., Eds.; CRC Press: Boca Raton, FL, 1991; Vol. 2, pp 1-24.

(26) Sprecher, C. A.; Basse, W. A.; J ohnson, W. C. Biopolymers 1979, 18, 1009-1019.

(27) Bokma, J . T.; J ohnson, W. C.; Blok, J . Biopolymers 1987, 26 893-909.

(28) Neidle, S. In DNA Structure and Recognition; Oxford University Press: New York, 1994; pp 29-35.

(29) Baase, W. A.; J ohnson, W. C. Nucl. Acid Res. 1979, 6, 797814

(30) Majidi, M. R.; Kane-Maguire, L. A. P.; Wallace, G. G. Polymer 1994, 35, 3113-3115.

(31) Majidi, M. R.; Kane-Maguire, L. A. P.; Wallace, G. G. Polymer 1995, 36, 3597-3599.

(32) Barisci, J . N.; Innis, P. C.; Kane-Maguire, L. A. P.; Norris, I. D.; Wallace, G. G. Synth. Met. 1997, 84, 181-182.

(33) Majidi, M. R.; Ashraf, S. A.; Kane-Maguire, L. A. P.; Norris, I. D.; Wallace, G. G. Synth, Met. 1997, 84, 115-116.

(34) Chevalier, J.-W.; Bergeron, J.-Y.; Dao, H. L. Macromolecules 1992, 25, 3325-3331. 
(35) MacDiarmid, A. G.; Epstein, A. J . Synth. Met. 1995, 69, 8592.

(36) Ong, C. H.; Goh, S. H.; Chan, H. S. O. Polym. Bull. 1997, 39 $627-632$.

(37) J ohnson, W. C. In Circular Dichroism Principles and Applications; Nakanishi, K., Berova, N., Woody, R. W., Eds.; VCH Publishers Inc.: New York, 1994; pp 523-524.
(38) Bokma, J. T.; J ohnson, W. C.; Blok, J . Biopolymers 1987, 26, 893-909.

(39) Tajmir-Riahi, H. A.; Theophanides, T.J . Biomol. Struct. Dyn. 1985, 3, 537-542.

MA0021287 